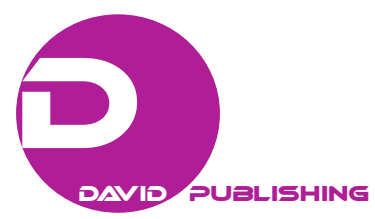

\title{
Changing Practices on Fatherhood in Postmodern Sweden*
}

\author{
TAN Ting-ting \\ Kyushu University, Fukuoka, Japan
}

\begin{abstract}
Sweden has transformed into a considerable gender equality and family-friendly society over the past half-century. Meanwhile, Swedish involved fathers have been not only regarded as the role model in many countries, but also been the focus of extensive research. However, the trajectory trends of shifting practices on fatherhood in postmodern Sweden and the reasons underlying the whole gender equality reforms are still not clearly illustrated and explored. Therefore, this paper tries to answer these questions by reviewing related literature from 1960 to 2017. It is found that although dual-earner and dual-carer models were proposed together as early as the mid-1960s, it was the former that proved easier to achieve. Since 1990s substantial shifts in the practices on fatherhood have occurred in Sweden. Nowadays, it becomes quite nature and common for Swedish fathers to take parental leave and share housework and childcare with their partners. The findings also highlight that in the transition towards a father-friendly state, the following causes and factors have interplayed with each other in Sweden: (a) Comprehensive and thorough grassroots feminist cultures and strategists have laid the foundations of gender equality in education, politics, economics and religion; (b) New images of fatherhood in the literature and medium programs have further shaped the values of respecting nurturing and soft fathers; (c) Father-friendly social policies have significantly constructed the dual-earner and dual-carer models; and (d) Organizational culture on balancing work and life has strongly supported the practices on involved and active fathering. Last, this paper concludes with a discussion on the importance of oral history and comparative studies on shifting fatherhood.
\end{abstract}

Keywords: Gender revolution; Gender equality; Dual-earner/carer model; Fatherhood; Father-friendly communities; Sweden

\section{Introduction}

Practices concerning fatherhood cannot be considered in isolation from broader ideas concerning gender roles, on the part of women as well as men (Bernhardt, Goldscheider, \& Turunen, 2016, p. 280; Bernhardt \& Goldscheider, 2006, p. 19). Therefore, it is necessary to consider practices to gender equality firstly, and then move on to analysis specifically of practices related to fatherhood. In terms of gender equality issue, it has been a hot topic in Sweden after the first debate on reforming gender relations in 1930s (Hearn, Nordberg, Andersson et al., 2012, p. 3). Further, it was put on the public policy agenda in the mid-1960s (Oláh, Bernhardt, \& Goldscheider, 2002, p. 35). Afterwards, Sweden has witnessed two phases of gender revolution, and thus become the forerunner of the second half of gender revolution.

The first half of gender revolution was that men should support women's participation in the labor market,

\footnotetext{
*Acknowledgements: I would like to thank Edward Vickers, Anita Nyberg, and Zeng Ming for reading and commenting on this paper.

TAN Ting-ting, Ph.D. candidate at Department of Comparative Education, Kyushu University.
} 
although women retained primary responsibility for taking care of children (Bernhardt, Goldscheider, \& Turunen, 2016, p. 271). In order to support dual-earner family pattern, the joint taxation of spouses supporting the traditional family was abolished in 1971. This individualization of the tax system encouraged married women to return to the labor market. It successfully made up the shortage of labor and enabled dual-earner family to have more economic benefits than a single high income family (Ferrarini, \& Duv, 2009, p. 3). Furthermore, in order to solve parents' dilemma between unpaid custody at home and paid work outside, the unpaid 3 months maternity leave in 1937 was shifted to the paid 6 months parental leave in 1974. Sweden thus became the first country in all the world offering paid parental leave to fathers (Seward, Yeatts, \& Zottarelli, 2002, p. 399). This paid 6 months parental leave was even extended to 15 months in 1990. Besides, the new gender equality laws were launched in 1980 and 1992 to grant women employment and parenthood (Hearn, Nordberg, Andersson et al., 2012, p. 3). As a result, Swedish female employment rate has been ranking one of the highest among the Western countries since the 1970s (Oláh \& Bernhardt, 2008, p. 1127). To be more specific, the percentage of female entering the labor market in Sweden has increased from 50\% in the mid-1960s to $80 \%$ in the early 1990s, which was almost comparable to that of men (Ferrarini \& Duv, 2009, p. 4). In addition, the employment rates of mothers with children aged 0-6 years in Sweden were even more significantly increased from 37\% in 1963 to 85\% in 1990 (Nyberg, forthcoming 2017).

Sweden has transformed into the second half of gender revolution since 1990s, in which men should share the responsibility of housework and childcare, and parents should have equal opportunities to work and take care of children (Oláh \& Bernhardt, 2008, p. 1106; Goldscheider, Bernhardt, \& Lappegård, 2015). Dual-carer model and men's two roles (i.e., father and worker) were more emphasized than dual-earner model and women's two roles (i.e. mother and worker) after 1990s. Furthermore, the dual-carer policies also geared more towards a reform of fatherhood by continually adjusting the length of parental leave and the benefit of non-transferable “daddy quota”. Father's one month non-transferable parental leave in 1995 was extended to two months (i.e., "the second daddy quota”) in 2002. In 2016, it was even extended to three months (i.e., "the third daddy quota”). As a result, 75\% of young Swedish men hold egalitarian attitudes towards gender equality (Bernhardt, Goldscheider, \& Turunen, 2016, p. 276) and expect to share the responsibility of housework and childcare with their partner (Johansson, 2011, p. 177). Comparing with other gender-equal countries (e.g., Norway), Swedes are more positive towards gender equality (Jakobsson \& Kotsadam, 2010, p. 142). Moreover, Sweden was awarded as the most gender-equal country in the world by the United Nations in 1995 (Evertsson, 2006, p. 415). According to the Global Gender Gap Report 2016, Sweden ranked No.4 in the most gender-equality countries in the world, with 0.815 overall score in the economic, educational, health-based and political indicators.

With the process of the gender revolution, the study on men and fatherhood in Sweden has also been increasingly valued since 1960s. Connell's theory and the concept of hegemonic masculinity problematized the male roles in the gender research in the 1960s (R. W. Connell \& R. Connell, 2005). In 1962, the landmark book The Life and Work of Women written by Dahlström Edmund in Swedish aroused the discussion on men and masculinity issue in the gender equality movement. After 1970s, men and fatherhood studies were carried out together with women's studies in Sweden. In the mid-1970s, the first masculinity and fatherhood research program was funded by the Swedish government (Hearn, Nordberg, Andersson et al., 2012, p. 4). From the mid-1980s, Anglophone theories and concepts on men and masculinity such as queer theory, discourse of masculinity theory and "third-wave feminism" have been diffused in Sweden. Comparing with other Nordic countries, there is more research on Swedish men and masculinities. 
However, the trajectory trends of shifting practices on fatherhood in postmodern Sweden and the reasons underlying the whole gender equality reforms are still not clearly illustrated and explored in the previous research. It is essential to identify these important research questions well. Therefore, this paper will firstly illustrate the transformation on dual-carer fatherhood by reviewing the related literature from 1960 to 2017. Furthermore, following the example of Sweden, many countries like Germany, Japan introduced a series of similar policies towards dual-earner and dual-carer states. However, their ranking of gender gap index and the number of involved fathers are not increased enough as anticipated. Welfare policies reform cannot solely explain the changes on fatherhood without other mediated factor, such as historical and cultural heritage, socio-economic situation, and expectations related to job and family. Sweden would be an ideal research case to study the interplay among welfare policies, cultural and socioeconomic on shifting fatherhood. A major contribution of this paper is to analyze the underlying causes and factors of Swedish practices on shifting fatherhood.

\section{Shifting Practices on Swedish Fatherhood}

Head to any Swedish streets on weekdays and weekends, and we will easily come across proud Swedish "Latte Papas" who are enjoying a coffee break or "Fika Papas" who are having coffee with pastries or sandwiches, before or after heading to the park with children. Most Swedish young adults expect to become a father (Kaufman \& Bernhardt, 2012) and enjoy taking parental leave. In terms of calculating the changing practices on Swedish shifting fatherhood, the division of taking parental leave and the time allocation of household work are the two main indicators.

\section{The Division of Taking Parental Leave}

Although Sweden is famous for its generous father-friendly welfare policies, Swedish fathers used to take less parental leave days than today. Specifically, it experienced five main phases: Firstly, after the implementation of paid 6 months parental leave for both mother and father in 1974, most fathers in Sweden transferred their rights to their partner (Nyberg, 2012, p. 73). In the early-1980s, fathers just took 5\% of total parental leave time (Johansson, 2011); Secondly, although there were numerous campaigns aiming at promoting more fathers to take the paid 9 months parental leave in 1990, the proportion of fathers taking parental leave increased very slightly; Thirdly, in order to encourage more fathers to take parental leave, father's one month non-transferable parental leave, namely "daddy quota”, was promulgated by Liberal Party in 1995. Meanwhile, the length of parental leave was extended to 15 months. Although 77\% of fathers took the "daddy quota" (Chronholm, 2002, p. 366), the total parental leave days taken by fathers was not significantly increased in Sweden; Fourthly, researchers (Almqvist \& Duvander, 2014) further find that if the length of parental leave becomes longer, more fathers will take parental leave and if fathers take longer parental leave, they will share more housework and childcare with their partner. Therefore, another influential policy-parental leave allowance leave was introduced by Social Democratic government in 2002. Only if both parents take at least two months parental leave, namely "the second daddy quota”, the whole parents can enjoy all 16 months parental leave which is much higher than the international standards. 32\% of fathers used 60-89 parental leave days in 2003 (Nyberg, 2012, p. 74). And the ratio of male recipients of parental leave allowance have increased from 25\% in 1990 to 45\% in 2015 (Nyberg, forthcoming 2017). The proportion of parental leave days taken by men has increased from 7\% in 1990 to $14 \%$ in 2001, reaching 26\% in 2015 (Swedish Social Insurance Agency, 2016). However, the aim of 1/10 parents share parental leave days equally in the 2010s was not really achieved. To promote more fathers to take parental leave, father's three months non-transferable parental leave, namely "the third daddy quota", was implemented in Sweden in 
2016.

\section{The Time Allocation of Household Work}

Gender division of housework and childcare research in Sweden is much less than gender division of paid work (Nyberg, 2012, p. 79). Time spent on childcare research is much less than that spent on housework since childcare presumed to have multi-aspects and to be more "emotionally based" (Dribe \& Stanfors, 2007, p. 4). Moreover, it is also hard to appropriately count the time spent on childcare (Sundström \& Duvander, 2002, p. 433; Forsberg, 2009, p. 199) especially from a longitudinal time-use study (Dribe \& Stanfors, 2007, p. 2). Although there were Swedish Time Use Surveys run by Statistics Sweden (SCB) in 1990/1991, in 2000 and in 2010/2011, the data were not sufficient to illustrate the changing gender differences in time allocation of housework and childcare. On the basis of limited Swedish Time Use Surveys data, Swedish women reduced their time on housework and childcare while Swedish men exhibited an opposite trend over 20 years. More exactly, on average, women spent 64 minutes less on housework per day in 2010 compared with 1990, and 14 minutes less compared with 2000. In contrast, men spent 22 minutes longer on housework per day in 2010 compared with 1990, and 11 minutes longer compared with 2000. Additionally, comparing 2010 with 1990, women spent 20 minutes less on childcare per day, whereas men spent 20 minutes longer on childcare per day. Besides, the official data in the Statistics Sweden 2010 showed that women and men spend equal time (7.2 hours per day) on gainful employment and housework in 2010. 70\% of Swedish men did 25\% of the total housework and ranked No.1 among the Nordic five gender-equality countries—Sweden, Finland, Iceland, Denmark and Norway (Nordenmark, Björk, Eydal, \& Rostgaard, 2014, p. 172), where there is a remarkably high gender equality and moderate decrease in fertility in contrast to other western welfare countries (Datta Gupta, Smith, \& Verner, 2006, p. 65).

However, it should be noted that Swedish gender equality attitudes do not always translate into more egalitarian behaviors within the family, especially with regard to childcare. Mothers in Sweden usually take the vast majority of parental leave days and often reduce working hours when children are young or sick, despite the significant increase in paternal involvement (Morgan, 2008, p. 405). Wells and Sarkadi's research (2012, p. 54) further points out that most mothers take the parental leave days in the infant's first year. Furthermore, researchers (e.g., Bianchi, 2000; Evertsson, 2006; Dribe \& Stanfors, 2007; Forsberg, 2007; Nyberg, 2012) also argue that Swedish mothers still spend more time on childcare than fathers. Besides, by analyzing the results of Swedish Child Level of Living Survey 2000, Evertsson' research (2006, p. 415) criticizes that parents' unequal division of housework impact gender inequality among children, e.g., Swedish girls still do more housework than boys at home.

\section{Causes and Factors of Swedish Shifting Fatherhood}

Fatherhood is socio-culturally constructed. Once the father role is constructed, it remains quite stable (Lupton \& Barclay, 1997, p. 16). Young generations in Sweden today are deeply attached to father-friendly communities and their values are significantly influenced by the cultural norms of involved fathers and dual-carer model. It is essential to consider what drives changing practices on Swedish fatherhood. Welfare policies have a significant impact on mothers' decision of returning the labor market and fathers' participation in childcare when their children are under school age (Sundström \& Duvander, 2002). However, policies also lead to unanticipated results. Taking Swedish family policies as the blueprint and role model, many welfare states, e.g., Germany and Japan take similar policies (Ferrarini \& Duvander, 2010). Unfortunately, both Germany and Japan have not encountered anticipated positive consequences of father-friendly family policies (Pfau-Effinger \& Smidt, 2011). 
Welfare policies reform cannot solely explain the changes on fatherhood in Sweden without other mediated factor, such as historical and cultural heritage, socio-economic and institutional. By analyzing underlying complicated and various causes and factors, this paper concludes that the father-friendly communities and a mass of involved fathers can be regarded as a result of a long historical process of interplaying among plural feminist cultures and strategies in education, politics, economics and religion, new images of fatherhood in literature and medium, a set of progressive and father-friendly laws and policies and organizational culture on work-life balance.

\section{Plural Feminist Cultures and Strategists in Education, Politics, Economics and Religion}

Comprehensive and thorough grassroots feminist movements laid the foundations of gender equality in Sweden. Swedish plural feminist cultures, i.e., liberal, collective, deregulation and radical feminist cultures, have promoted an "F world" (Feminist world) permeating all aspects of societies (e.g., education, politics, economics and religion), ensuring that considerations of gender equality feature prominently in all spheres of public debate over social policy.

To achieve gender equality, the classical liberal and feminists of whatever stamp tended to agree on the important role of education in transforming gender practices (Eduards, Gustafsson, \& Rönnblom, 1997). Sweden witnessed three main education reforms that were significant in promoting the engagement of girls in male-oriented education, and later of women in traditionally male occupations. The first step was to improve all girls' and boys' education level by implementing compulsory nine-year basic education in 1960 (Meghir \& Palme, 2005). The structures and curriculum of Swedish schooling also began to be permeated by the principles of gender equality. Boys and girls shared the same classrooms and schools during the nine compulsory years. The second step was to eliminate attitudes towards gender differences in the learning of what had been regarded as stereotypically 'male' subjects by commencing a far-reaching reform in the 1990s (Bauer, Askling, Marton, \& Marton, 1990). From that time on, more gender-neutral characters featured in textbooks. Meanwhile, more knowledgeable women teachers with sufficient skills and positive attitudes about gender roles were coming into the profession, while in schools new collaborative pedagogic practices were introduced, promoting studying in mixed-gender pairs or small groups. The increased recruitment of female teachers at all levels was related to a third area of reform, aimed at achieving gender equality in higher education, (Korpi, Ferrarini, \& Englund, 2013). As a means of reducing educational inequality, a series of new institutes of higher education were established during the 1970s (Dryler, 1998, pp. 65-66), and from the 1960s to the 1980s, Sweden was at the forefront of “developed” societies in terms of boosting women's higher education participation rate. During the 1980s, nearly twice as many women as men graduated from college (Lagerlöf, 1993, p. 21). In 1995 Swedish women aged 25-64 were as educated as men and in the early 2000s much more Swedish women were educate than men (Oláh \& Bernhardt, 2008, pp. 1123-1124). Today, around two thirds of bachelor degrees in Sweden are received by women. Nearly equal numbers of male and female students are receiving postgraduate and doctoral studies in Sweden now. Education level has implication on parenthood and gender division of labour. Men with more egalitarian attitudes are likely to get married with egalitarian women and delay to become a father (Bernhardt, Goldscheider \& Turunen, 2016, pp. 272-273). The women holding a gender equality concept are more likely to delay to have children and require share responsibility at home (Bernhardt, Goldscheider, \& Turunen, 2016, p. 270). Nordenmark, Björk, Eydal, and Rostgaard's research (2014) showed that the mothers' education level has greater importance on the level of involvement in housework and childcare than fathers' education level because of that highly educated women push their partners to share more responsibility (Nordenmark, Björk, Eydal, \& 
Rostgaard, 2014, p. 180). Therefore, new roles of women have a remarkable impact on gender equality and stimulate the new roles of men.

To overcome women's subordination, it is crucial for women to have representatives in parliament and more generally in state and local authorities, as well as to have representation in labor unions and other interest groups. By applying a self-defining concept of feminism in political and media discourses, the Swedish collective feminist culture in the State Feminism and Interest Group Feminism have promoted women's power and voices in politics and labor markets. The rules, ensuring the presence of female candidates in every election, brought significant advances in women's representation: (a) In 1947, Karin Kock became the first female government minister and the first economics professor in Sweden; (b) In 1968, Sweden became the first country in the world to frame a government policy of gender equality (J. A. Wiles, C. R. Wiles, \& Tiernlund, 1995); (c) In 2015, Swedish women made up 45\% of the members of the Swedish Parliament, and 52\% of the Ministers in the Swedish Government, which declared itself "a feminist government, devoted to a feminist foreign policy”. ${ }^{1}$ Furthermore, whenever new policies or laws are considered, gender mainstreaming has been taken into account. In the governmental annual budget, there is always a particular intention of distributing money on gender equality, for instance, 252 million Krona were allocated on gender equality in 2014. As a result, Swedish women have gotten the equal rights as men and Swedish powerful women who hold a position in politics have promoted Sweden to become a world leader in gender equality. It is just like Hornscheidt (2008) pointing out that feminism has not only become crucial branding strategies for nearly all Swedish parties, but also become "a central characteristic of national identity" and "positive international perceived image”.

Instead of relying on male economic income, two principles, namely that women should be liberated from economic dependence on husbands and men should be involved in family life, have gradually become enshrined in economic and social policy through parliamentary action. The Prime Minister Olof Palme argued convincingly about the need for female employment and gender equality. The "solidarity wage policy" from the mid-1950s to the early 1980s provided commitment to the Swedish goal of equal pay for equal work, including gender equality and wage agreement in 1960, discrimination in general law in 1974, equal treatment of male and female employees agreement in 1977, and equal opportunities for males and female legislation in 1980 (Le Grand \& Tsukaguchi-Legrand, 2003, p. 66). It is worth noting that since 1971 Sweden has chosen individual tax system in order to prompt couples to choose dual-earner model. Women's increasing participation in the labor market has been facilitated by changes in the structure of the Swedish economy, and the taxation system. Since the 1980s, the spread of "standardized industry-wide systems" and automation, and the shifting of much manufacturing industry overseas (not least to China), has depressed the demand for workers in traditionally male occupations (such as heavy industry and mining), while the growth of service-sector employment has increased demand for so-called 'knowledge workers', carers and customer-facing personnel of various kinds (OECD, 1994, p. 110; Sarch, 1997, p. 29). Moderately-skilled and special professional positions especially in entertainment, advertising, franchises, media, IT network, sports and some types of financial services have been much more accessible to highly educated women (OECD, 1994, p. 124). These economic and labor market shifts have been particularly pronounced in Sweden. In 1991, "housewife deduction" was abolished. By 1994, there was the lowest wage gap and the percentage of married women (84\%) in the labor force was the highest among industrialized countries. In 2007, the joint taxation of wealth was abolished. In 2012, the number of Sectoral Gender Segregation Indicators

\footnotetext{
${ }^{1}$ Retrieved from https://sweden.se/society/sweden-gender-equality/.
} 
(SGS) in Sweden was higher than EU-27 level, Sweden benefits from letting women to take 'typically male' occupations and men to occupy 'typically female' jobs. As a whole, the percentage of mother with children aged 0-6 has increased from 37\% in 1963 to 80\% in 2014 and the employment gap between fathers and mothers has decreased from 35\% in 1963 to 12\% in 2015 (Nyberg, forthcoming 2017). In all, the gender pay gap in Sweden is lower than OECD average.

Towards a more liberal society, Sweden has abolished the remains of religious values and has been shaping secular way of thinking in many fields. Firstly, Sweden has been a relatively secular and religious freedom country since 1951. Unlike other four Nordic countries, Sweden builds no extra official state churches since 2000. According to 2012 The Global Index of Religiosity and Atheism Survey, only 29\% of Swedes claim to be religious and only $8 \%$ of Swedes regularly take part in any religious services. ${ }^{2}$ Secondly, feminist opposed the traditional religious labeling non-marital relationship. The new type of family- Cohabitation with children is socially accepted. In 1936, around 50\% of newborn children's parents are not in wedlock (Bergman \& Hobson, 2002, p. 97). And the number of cohabitation family took up more than $40 \%$ of Swedish family patterns in 2012. No matter what kind of family pattern, parents always take their rights and duties to their children. Lastly, Sweden becomes one of the forerunners of breaking the male-dominated religious trend. In the traditional stereotype of religious family, fathers are moral arbiters within the family and church (Jantera-Jareborg, 2009). Fathers provided financial support and engaged in religion-related responsibilities, such as moral teaching and religious instruction. In terms of gender equality, Antje Jackelén became the first female archbishop in 2013. Today $45 \%$ priests are women. ${ }^{3}$ Sweden has already become one of the least religious countries and one of the most liberal states. The secular society offers Swedes more freedom to explore the various roles of father rather than limiting to father's traditional religious role.

\section{New Images of Fatherhood in Literature and Medium}

The image of a businessman has been replaced by an active father in the literature and medium programs. There are two well-known Swedish storybooks and television series which have inspired Swedish new attitudes and values on parenting and fathering: one is Pippi Longstocking (Boken om Pippi Langstrump) published in 1945, while the other one is Alfie Atkins (AlfonsÅberg) published in 1972. Pippi Longstocking describes a playful and unpredictable girl, who often makes fun of unreasonable adults and challenges. Alfie Atkins portrays a pretty ordinary boy, who lives with his nice and positive father and experiences many ordinary events without mentioning the mother.

In 1970s, a series of posters on nurturing father with children in government campaign, for instance the famous Swedish weight lifter, have intensively shifted the Swedish culture and value towards being proud of soft and nurturing fathers. In 1990s, the song "Papa come home" sang by Evert Taube, one of Swedish foremost troubadour in the 20C, has promoted men into active caregivers and increased fathers' usage of parental leave (Bergman \& Hobson, 2002). Aiming to improve father's' professional caring knowledge and skills, build a social network and increase awareness of social and governmental supporting parental friendly communities, governmental training project for fathers was set up by more father-trainers in local communities in 1994. Rather than being a passive observer, Swedish father can positively participate in the whole process of delivery. At the beginning of 21C, Swedish Social Insurance Agency official Facebook constantly broadcasts the newest funny

\footnotetext{
${ }^{2}$ Retrieved from https://sweden.se/society/10-fundamentals-of-religion-in-sweden/.

${ }^{3}$ Retrieved from https://sweden.se/society/10-fundamentals-of-religion-in-sweden/.
} 
videos related to the usage of parental leave. If fathers refuse to take the "daddy quota", they will lose the golden chance to build a good relationship with family members. In contemporary Sweden, recent debates on gender equality at private sphere and discourses on new definition of masculinity and fatherhood are currently flourishing in Swedish mainstream media (Bredström, 2003). By watching Gender Debate program which is broadcasted every Sunday, it is easy for Swedes to follow the updated information of gender issue. Furthermore, compared to other custody like cleaning and washing clothes, it is a "fun option" for men to cook (Neuman, 2016). By propagating male celebrity chefs and male using cooking apps on TV, cookbooks, magazines and food websites, it successfully leads men to take more domestic responsibilities. In 2015, 25\% of children preferred the meals cooked by their father. In addition, On Jan.30, 2017 Swedish comedy show Bonus Family (Bonusfamiljen), reflecting the story of how modern bonus family deal with the practices on taking care of various kids, e.g., stepchildren, cohabitation children, was broadcasted by SVT every Monday and immediately got a very high rating. The conflict between new pattern of family and parents' traditional practices got widespread attention and discussion.

\section{Father-friendly Social Policies}

Father-friendly social policies are the cornerstones of promoting men to become involved and active fathers. Different public policies reinforce different family patterns. That is to say, the powerful and executive public policy can support either men's traditional roles, or egalitarian roles, or even involved and emotional roles. "Male breadwinner" policies support "separate spheres" for men and women whilst "Worker-carer" policies reinforce gender equality (Oláh, Bernhardt, \& Goldscheider, 2002, p. 26). In Sweden, gender equality and expanded male role has become Swedish state identities (Towns, 2002). Apart from a brief period of Conservative-led coalition government in the early 1990s, the Social Democratic Party (SDP) was the dominant force in Swedish government. SDP is a facilitating state or enabling state that applied the democratic values, equality and justice into social policies. As a result, Sweden has maintained a considerable stable governmental policy to address gender equality in a more wider range of areas and to create good conditions for both men and women to enjoy the same power and opportunities in the workplace and domestic area by pointing out the requirement of career women and possibilities of reconciling work and family life for parents, especially for fathers. Swedish government has been striving to make sure that power and resources are equally distributed between men and women and fathers take as much responsibility as mothers for the housework and childcare. More exactly, gender equality has been a goal of Sweden's leading parties and has pervaded all aspects of government policies since the 1960s (Nordstrom, 2010, p. 49). From the late 1960s and onwards there has been an increased official interest in strengthening women's position by implementing the expansion of full day public day-care from the child's first birthday, extended earnings-related parental leave benefit with long duration, individualized income taxation and custody legislation (Lindvert, 2002; Ferrarini \& Duvander, 2009, pp. 1-3). Furthermore, father-friendly social policies have become a matter of left-right consensus in Swedish politics since the 1990s. It was around that time the policies started to address the reform of fatherhood, especially focusing on encouraging men to take as much responsibility as mothers for children and household duties, as well as freeing women's time for labor market work (Almqvist \& Duvander, 2014), such as, "Child allowance” rather than "Family allowance"; "Gender equality bonus" that parents have joint custody and share the parental benefit may be entitled to gender equality bonus; "16 months parental leave with 3 months daddy quota" in 2016 rather than "Maternity leave" or "Paternity leave”. Besides, in 2017 expansion of the law, employers are forbidden to unfairly treat any employee or job 
applicant who is going to take parental leave or has been taken.

\section{Organizational Culture on Balancing Work and Life}

Organizational culture on balancing work and life in Sweden plays a key vital role in supporting more and more involved fathers. Bygren and Duvander's research (2006) indicates that the workplace status' (e.g., manager's attitude on the division of parental leave, the percentages of female managers) influence father's usage of parental leave more than father's individual characters. Aiming to balance work and life, Swedish companies and institutions take four main strategies: (a) Encouraging male managers and male employees to take parental leave through full time or part time. Large companies in Sweden stimulate fathers to take parental leave by topping-up the parental leave benefit from $80 \%$ to $100 \%$ of previous salaries. In 2017 expansion of the law, employers are forbidden to unfairly treat any employee or job applicant who is going to take parental leave or has been taken. Companies' caring values also strongly support fathers to be more active in child caring. More and more fathers are receiving father-friendly perceptions from top managers. Nowadays, if employed fathers take parental leave, they will receive more peers and leaders' respect with the children-oriented value. It is shameful to be a work-oriented father. Besides, the workplace is also encouraging and supporting fathers to share their happiness and difficulties during fathering with their colleagues (Wissö \& Plantin, 2015, p. 267); (b) Supporting women's equal employment opportunity. After 1992, every company carries out the "action plan for equality"-both men and women have some responsibility for breadwinner and caregiver and more and more companies are more likely to support involved fathers, although Swedish private companies lag behinds public work organizations in terms of father-friendly supports. Besides, organizational cultures are also shattering the glass ceiling with more and more female managerial positions. In 2016, Female municipal managers in Sweden received higher salaries than male for the first time in history; ${ }^{4}$ (c) Carrying out flexible work. $25 \%$ employed fathers are able to decide work time (Björnberg, 2016). In terms of scores on allowing flexibility in time and place, Sweden is awarded the highest among European countries (Hobson, 2016). Parents in Sweden are able to bring their children to workplace and work at home, and have the right to plan work day and flexible work hours; (d) Reducing working hours to meet family needs. Although in the persistence of male-dominated workplace and “male model of work", all men's working hours have decreased from 47 hours per week in 1950s to 40 hours in 1973 (Nyberg, forthcoming 2017) and 20\% companies in Sweden reduced working hours in 2016 (Haas \& Hwang, 2016).

Apart from that, there are numerous formal and informal supports to Swedish fathers from both practical help and emotional support. Antenatal classes started to open for pregnant women and their partner in the late 1970s and separate groups for fathers in the late 1980s (Swedin, 1996, pp. 28-29). After 2006 nurses also tend to offer professional tips to fathers and rainbow family (parents are gay or lesbian couples) in order to achieve a gender equal society with super gender-neutral ideologies and more emotional fathers (Nordenmark, Björk, Eydal, \& Rostgaard, 2014, p. 166). There are always a series of children's centers to make up the absent time of working parents, such as "Leisure time centers", which are open during vocations and before and after schooling time; "Daily-care centers”, which are available for parents with up to 6 years old. ${ }^{5}$ During the parents' time off work, nearly 95-99\% of Swedish parents used the Child Health Centers (Wells \& Sarkadi, 2012, p. 25). In the capital-Stockholm, parents who are pushing children in prams and pushchairs can enjoy free public bus rides and

\footnotetext{
${ }^{4}$ Retrieved from https://www.thelocal.se/20160225/women-bosses-overtake-men-in-swedens-wage-race.

${ }^{5}$ Retrieved from http://www.everyculture.com/Europe/Swedes-Marriage-and-Family.html.
} 
can board buses' large doors. Besides, in the aspect of emotion, Swedish women also positively support Swedish men to be more involved fathers (Johansson, 2011).

\section{Conclusions and Discussions}

The discourse on gender equality and dual-earner/carer in workplace and domestic sphere has been hot debated and explored/practiced in Sweden since the mid-1960s. Now Swedish gender order has been rebuilt to be more gender-equality and gender-neutrality, and thus traditional hegemonic masculinity has not been preserved. Particularly, hegemonic ideals of masculinity and fatherhood have been challenged, and Swedish fathers have been taking much greater responsibility of housework and childcare than before. A substantial shift in the general culture of new Swedish fatherhood has occurred after 1990s. Swedish father has been increasingly expected to be an involved and active father in private sphere. It has been quite nature for fathers to take parental leave and share housework and childcare with their partners. As a result, gender equality has become a Swedish national character and involved fathers in a dual-earner and dual-carer setting have become a matter of Swedish national pride.

The development of gender equality and involved fathers can be regarded as a result of a long historical process involving men and women's liberation and equal right in both of the public and private sphere. Comprehensive and thorough grassroots feminist cultures and strategists laid the foundations of gender equality in education, politics, economics, and religion. The dual-earner model was promoted by women's extensively high education levels, positive political participation, economic autonomy and freedom, the independence of marriage, and religious freedom, and the institutionalization of women-friendly welfare systems. During the process of achieving dual-earner model, Swedish women demanded more freedom in the private places. New images of fatherhood in the literature and medium have further challenged the ideologies of traditional patriarchal fathers and shaped the values of nurturing and soft fathers with respects. Father-friendly social policies (e.g., individualized income tax system, extensive public day-care, and generous parental leave and "daddy quota") have gradually constructed the dual-earner and dual-carer model. Organizational culture on balancing work and life (e.g., children-oriented value, flexible work, reduce working hours) has supported the practices on involved and active fathering. In the transition towards forefront reforms and development on gender equality and dual-earner/carer model, all the above causes and factors have been intersected with each other, like a package.

Swedish fatherhood is of great interest since Sweden is the archetype of Nordic model and has transformed from a traditional hegemonic masculinity country to one of the most generous father-friendly welfare states, boasting the most "comprehensive egalitarian" parental leave policy countries over the past half of a century (Wells \& Sarkadi, 2012, p. 25). Unlike other welfare states, the progressive revolutions and reforms of gender equality and involved father in Sweden has been more completed and thorough. It is not only women's two roles (i.e., mother and worker) were emphasized but also men's two roles (i.e., worker and father) were paid attention from as early as the mid-1960s. These dual-earner and dual-carer models were proposed together, but it was the former that proved easier to achieve. Swedish experience appears to show that the dual-earner model represents a first and more readily achievable step towards gender-equality in employment and the public sphere, while a dual-carer model is required to achieve a sharing of responsibility in the private sphere that allows women (especially mothers) to pursue their careers to the same extent as men. It is worth noting that Swedish practical dual-carer model more or less laid a foundation for moving to practical dual-carer model by the second half of gender revolution. Now Sweden is home to both "Latte mommy" and "Latte daddy", who are pushing prams and 
sharing coffee with each other while feeding their babies in cafés and/or parks in any Swedish city or town. It is quite common to come across "Working women" and "Leaving daddy" (father is taking parental leave or children sick leave).

It is still worth noting that although gender-segregated labor market, traditional male-dominated jobs and gender wage gap has been broken up (Nyberg, forthcoming 2017), the powerful positions are still mainly controlled by man in Sweden. Today, men take up three-quarters of all Swedish companies' board members and occupy 77\% of professors in university. Haas and Hwang's research (2009) criticizes that formal and informal support from companies, managers and colleagues to white-collar fathers are much more than to blue-collar fathers. Furthermore, in the transition towards a more involved and emotional fathers or parents, it is worth noting that some researchers criticize that Swedish gender equality attitudes do not always translate into more egalitarian behaviors in the family. Although father's usage of parental leave days has sharply increased, mothers still take the majority of parental leave days. The time of sharing housework and taking care of children in daily life seems hard to calculate accurately. More effective methodologies like life story of practices on fatherhood are worth exploring. Furthermore, by comparing changes and causes on fatherhood in other communities and states, it is possible to unpack the standard chicken and egg problem: social policies shape the practices on fatherhood or the currently fathering pressure the political reforms (Bergman \& Hobson, 2002). Last, the reasons on changing fatherhood in Sweden are much more complicated, more oral history studies on shifting fatherhood are needed to further deeply analyze the underlying causes and factors.

\section{References}

Almqvist, A. L., \& Duvander, A. Z. (2014). Changes in gender equality? Swedish fathers' parental leave, division of childcare and housework. Journal of Family Studies, 20(1), 19-27.

Bauer, M., Askling, B., Marton, S. G., \& Marton, F. (1999). Transforming universities: Changing patterns of governance, structure and learning in Swedish higher education. Higher Education Policy Series 48. Taylor and Francis, Inc. 325 Chestnut St., Philadelphia, PA 19106.

Bergman, H., \& Hobson, B. (2002). Compulsory fatherhood: The coding of fatherhood in the Swedish welfare state. Making men into fathers: Men, masculinities and the social politics of fatherhood, 92-124.

Bernhardt, E., Goldscheider, F., \& Turunen, J. (2016). Attitudes to the gender division of labor and the transition to fatherhood: Are egalitarian men in Sweden more likely to remain childless? ActaSociologica, 59(3), 269-284.

Bianchi, S. M. (2000). Maternal employment and time with children: Dramatic change or surprising continuity? Demography, 37, 410-414.

Björnberg, U. (2016). Nordic family policies in a European context. Sociology and Anthropology, 4(6), 508-516.

Bredström, A. (2003). Gendered racism and the production of cultural difference: Media representations and identity work among “immigrant youth” in contemporary Sweden. Nora: Nordic Journal of Women's Studies, 11(2), 78-88.

Bygren, M., \& Duvander, A. Z. (2006). Parents’ workplace situation and fathers’ parental leave use. Journal of Marriage and Family, 68(2), 363-372.

Connell, R. W., \& Connell, R. (2005).The male roles. In Masculinities (pp. 21-27). Berkeley, CA: University of California Press.

Datta Gupta, N., Smith, N., \& Verner, M. (2006). Child care and parental leave in the Nordic countries: A model to aspire to? IZA DP No. 2014. Bonn: IZA. debatten, edited by Hans Hederberg. Stockholm: Bonnier.

Dribe, M., \&Stanfors, M. (2007). Fatherhood and men's everyday time use in Sweden, 1990/91-2000/01 (Paper for session 48 "Work and Family: A Father's Perspective” at The Annual Meeting of the Population Association of America, New York, pp. 29-31). Retrieved from http://paa2007.princeton.edu/papers/70354

Dryler, H. (1998). Educational choice in Sweden: Studies on the importance of gender and social contexts (Doctoral dissertation, The Swedish Institute for Social Research, Stockholm University).

Eduards, M., Gustafsson, G., \&Rönnblom, M. (1997). Towards a New Democratic Order?: Women's Organizing in Sweden in the 1990s. Bucharest: Publica. 
Evertsson, M. (2006). The reproduction of gender: Housework and attitudes towards gender equality in the home among Swedish boys and girls. The British Journal of Sociology, 57(3), 415-436.

Ferrarini, T., \& Duv, A. Z. (2009). Swedish family policy controversial reform of a success story. Friedrich Ebert Stiftung, 3, $1-10$.

Ferrarini, T., \& Duvander, A. Z. (2010). Earner-carer model at the crossroads: Reforms and outcomes of Sweden's family policy in comparative perspective. International Journal of Health Services, 40(3), 373-398.

Forsberg, L. (2007). Negotiating involved fatherhood: Household work, childcare and spending time with children. NORMA: Nordic Journal for Masculinity Studies, 2, 109-126.

Forsberg, L. (2009). Involved parenthood: Everyday lives of Swedish middle-class families (pp. 1-199). Linköping University Electronic Press.

Goldscheider, F. Bernhardt, E., \& Lappegård, T. (2015). The gender revolution: A theoretical framework for understanding new family-demographic behavior. Population and Development Review, 42(2), 207-239.

Haas, L., \& Hwang, C. P. (2009). Is fatherhood becoming more visible at work? Trends in corporate support for fathers taking parental leave in Sweden. Fathering, 7(3), 303.

Haas, L., \& Hwang, C. P. (2016). “It’s about time!”: Company support for fathers' entitlement to reduced work hours in Sweden. Social Politics, 23(1), 142-167.

Hearn, J., Nordberg, M., Andersson, K., Balkmar, D., Gottzén, L., Klinth, R., ... \& Sandberg, L. (2012). Hegemonic masculinity and beyond: 40 years of research in Sweden. Men and masculinities, 1097184X11432113, 1-25.

Hobson, B. (2016). Fathers' capabilities for work-life balance in Sweden: The unfinished revolution (特集 work-family balance of families with small children: How to achieve gender equality in parenting). 家族社会学研究= Japanese Journal of Family Sociology, 28(2), 193-206.

Hornscheidt, A. (2008). Sweden-the world's most feminist society: An analysis of current Swedish media debates and person appellation forms as a tool within CDA. Journal of Language and Politics, 7(3), 391-412.

Jakobsson, N., \& Kotsadam, A. (2010). Do attitudes toward gender equality really differ between Norway and Sweden?. Journal of European Social Policy, 20(2), 142-15.

Jantera-Jareborg, M. (2009). Family law in a multicultural Sweden-The challenges of migration and religion. In Uppsala-Minnesota Colloquium: Law, Culture and Values.

Johansson, T. (2011). Fatherhood in transition: Paternity leave and changing masculinities. Journal of Family Communication, 11(3), 165-180. Karlstad University.

Kaufman, G., \& Bernhardt, E. (2012). His and her job: What matters most for fertility plans and actual childbearing?. Family Relations, 61(4), 686-697.

Korpi, W., Ferrarini, T., \& Englund, S. (2013). Women’s opportunities under different family policy constellations: Gender, class, and inequality tradeoffs in western countries re-examined. Social Politics: International Studies in Gender, State \& Society, 20(1), 1-40.

Lagerlöf, E. (1993). Panel of experts on women work and health: National report Sweden. Stockholm: Socialdepartementet.

Le Grand, C., \& Tsukaguchi-Legrand, T. (2003). Gender, employment systems and labour market outcomes in Japan and Sweden. Women in Japan and Sweden: Work and Family in Two Welfare Regimes, 63-92.

Lewis, J., \& Åström, G. (1992). Equality, difference, and state welfare: Labor market and family policies in Sweden. Feminist Studies, 18(1), 59-87.

Lindvert, J. (2002). A world apart. Swedish and Australian gender equality policy. Nora: Nordic Journal of Women's Studies, 10(2), 99-107.

Lupton, D., \& Barclay, L. (1997). Constructing fatherhood: Discourses and experiences. Thousand Oaks, CA: Sage Publications.

Morgan, K. J. (2008). The political path to a dual earner/dual carer society: Pitfalls and possibilities. Politics \& Society, 36(3), 403-420.

Neuman, N. (2016). Stories of masculinity, gender equality, and culinary progress: On foodwork, cooking, and men in Sweden (Doctoral dissertation, Acta Universitatis Upsaliensis).

Nordenmark, M., Björk Eydal, G., \& Rostgaard, T. (2014). Gender regime, attitudes towards childcare and actual involvement in childcare among fathers. In Fatherhood in the Nordic Welfare states: Comparing care policies and practice (pp. 163-186). Bristol, UK: Policy Press.

Nordstrom, B. J. (2010). Culture and customs of Sweden. California: Greenwood.

Nyberg, A. (2012). Gender equality policy in Sweden: 1970s-2010s. Nordic Journal of Working Life Studies, 2(4), 67-84. 
Nyberg, A. (Forthcoming 2017). From Kick-start to U-turn? Gender equality in Sweden. In B. English, M. E. Frederickson, and O. Sanmiguel-Valderrama (Eds.), Gender and work in the global economy. London: Routledge, forthcoming 2017.

Oláh, L. S., \& Bernhardt, E. (2008). Sweden: Combining childbearing and gender equality. Demographic Research, 19(28), 1105-1144.

Oláh, L. S., Bernhardt, E. M., \& Goldscheider, F. K. (2002). Coresidential paternal roles in industrialized countries: Sweden, Hungary, and the United States. Making Men Into Fathers: Men, Masculinities and the Social Politics of Fatherhood, 25-57.

Organization for Economic Co-operation and Development. (1998). Women and structural change: New perspectives. Paris, France: Organization for Economic.

Pfau-Effinger, B., \& Smidt, M. (2011). Differences in women’s employment patterns and family policies: Eastern and western Germany. Community, Work \& Family, 14(2), 217-232.

Sarch, Y. (1997). Outside academia: The changing job market and its influence. Women as Leaders and Managers in Higher Education, 28-34.

Seward, R. R., Yeatts, D. E., \& Zottarelli, L. K. (2002). Parental leave and father involvement in child care: Sweden and the United States. Journal of Comparative Family Studies, 387-399.

Sundström, M., \& Duvander, A. Z. E. (2002). Gender division of childcare and the sharing of parental leave among new parents in Sweden. European Sociological Review, 18(4), 433-447.

Swedin, G. (1996). Modern Swedish fatherhood: The challenges and the opportunities. Reproductive Health Matters, 4(7), 25-33.

Swedish Social Insurance Agency. (2016). Social insurance in figures 2016. Stockholm, Sweden: Lenanders Grafiska AB.

Towns, A. (2002). Paradoxes of (In) equality something is Rotten in the gender equal state of Sweden. Cooperation and Conflict, 37(2), 157-179.

Wells, M. B., \& Sarkadi, A. (2012). Do father-friendly policies promote father-friendly child-rearing practices? A review of Swedish parental leave and child health centers. Journal of Child and Family Studies, 21(1), 25-31.

Wiles, J. A., Wiles, C. R., \& Tjernlund, A. (1995). A comparison of gender role portrayals in magazine advertising: The Netherlands, Sweden and the USA. European Journal of Marketing, 29(11), 35-49.

Wissö, T., \& Plantin, L. (2015). Fathers and parental support in everyday family life: Informal support in Sweden beyond the auspices of the welfare state. Families, Relationships and Societies, 4(2), 267-280. 